\section{MITI reveals 1992 budget}

\section{Tokyo}

NANOTECHNOLOGY and brain-like computers are the new targets of research in the 1992 budget request of the powerful Ministry of International Trade and Industry (MITI). The ministry also plans to boost its already large budget for development of 'environment friendly' technology and to make a substantial budget allotment for reorganization of its research laboratories in Tsukuba, where much of the new nanotechnology research will be carried out.

The budget is scheduled to be submitted to the Ministry of Finance at the end of this month. The request is likely to undergo minor modification in negotiations with the ministry before it is submitted to the Diet for approval early next year, but science and technology budgets seldom experience major change during this process.

MITI's next-generation computer project to develop neural network and optical computers that mimic the human brain (see $\mathrm{Na}$ ture 351, 336; 30 May 1991) is set to get underway next year with a budget of about $¥ 900$ million (\$6.7 million). Ultimately, MITI hopes to pour several hundred million dollars into the project as the ministry has done for its predecessor, the fifthgeneration computer project. In a surprising move, MITI has also made a substantial budget request (albeit reduced from this year) to continue development of the fifth-generation computer. The 10-year fifth-generation project, which sparked competing government projects around the world, was due to end this fiscal year.

Another key budget item is a small request of $¥ 30$ million ( $\$ 220,000$ ) to begin a new large-scale (ogata) project to develop nanotechnology. MITI and industry hope to invest over $\$ 200$ million in the 10-year Angstrom Technology Project,

bon dioxide. The ministry requests $¥ 8,300$ million ( $\$ 61$ million) - 25 per cent above this year - largely for government/industry projects organized by the ministry's Research Institute of Innovative Technology for the Earth, which will open in 1992.

Under a painful process that has met much resistance, the ministry has been cutting back funding for development of coal-liquefaction technology because coal

\begin{tabular}{lcr} 
MITI science and technology & $\begin{array}{r}\text { Thousand } \\
\text { million yen }\end{array}$ & $\begin{array}{r}\% \text { change } \\
\text { from 1991 }\end{array}$ \\
\hline Total R\&D budget & 264.5 & +3.4 \\
Japan Key Technology Centre & $27.0 *$ & -5.6 \\
Basic technologies for future industries & 8.3 & +5.7 \\
Large-scale industrial projects & 15.0 & +4.9 \\
Sunshine new energy sources project & 27.0 & +8.7 \\
Moonlight energy-saving technology project & 11.9 & +4.7 \\
Unmanned space platform & 5.8 & +3.6 \\
Fifth-generation computer & 3.6 & -49.7 \\
Sixth-generation computer (NIPT) & 0.9 & +842.7 \\
Global environment & 8.3 & +22.4 \\
Intelligent Manufacturing System & 0.8 & +197.8 \\
Human Frontier Science Program (HFSP) & $4.2 * *$ & +10.7 \\
Elucidation of biological functions & 0.3 & -12.7 \\
$\quad$ (domestic HFSP) & & \\
NEDO international grants & 0.7 & +53.4 \\
Reorganization of Tsukuba & 14.9 & +11.3 \\
$\quad$ Science city institutes & & \\
\hline * Budget shared with Ministry of Posts and Telecommunications & & \\
** Budget shared with Science and Technology Agency &
\end{tabular}
liquefaction does not help reduce carbon dioxide emissions, and, thus, does nothing to alleviate current concerns about global warming. Instead, MITI plans to launch a new project next year with an initial budget request of $¥ 800$ million to develop 'clean coal technology' that will reduce carbon dioxide emissions from coal use.

MITI and the Science and Technology Agency hope to increase funds for the Human Frontier Science Program, which supports international research on the brain and molecular biology, with a request for an additional 11 per cent for next year to support five more grants than the 30 budgeted for this year. But it seems the programme has

which will be centred at a new interdisciplinary research centre in Tsukuba science city (see Nature 352, 650; 22 August 1991). The ministry also allocates nearly $¥ 15,000$ million ( $\$ 110$ million) for the related reorganization of its institutes in Tsukuba

MITI continues to pour more money into the development of technology to protect the global environment, such as CFC substitutes, biodegradable plastics, and technology to absorb and utilize car- already reached close to the maximum ceiling the Ministry of Finance will allow.

The Intelligent Manufacturing System project to develop automated factories of the future, which is intended as a followup to the Human Frontier Science Program, also gets a significant boost to $¥ 810$ million. But the hoped-for international cooperation in the project still remains in limbo, waiting for an agenda from the United States for an international feasibility study. David Swinbanks

\title{
MITI hopes to foster outside interaction
}

Included in MITI's budget request (see above) are proposals to revise Japan's laws to encourage Japanese government laboratories and government-industry research consortia to interact more with the outside world.

One amendment will provide special tax exemptions for research consortia that include non-Japanese companies. The move is part of the ministry's policy of 'technoglobalism', which aims at encouraging interaction with overseas companies to counteract a perceived 'technonationalism' in the United States, where some government and industry officials are believed to be trying to bar Japanese access to leading US technology.

Under the proposed new law, which MITI officials expect to take effect next April, international consortia will be exempt from taxes that are normally imposed on any left-over funds consortia have at the end of each fiscal year. At present, consortia have to spend all money in their fiscal-year account or face such taxation. This discourages them from carrying over funds to the next fiscal year.

A second amendment, proposed by MITI and the Science and Technology Agency, is intended to allow researchers in national laboratories to work for pay in outside organizations, such as private companies or overseas organizations, and to let government researchers receive funds from outside sources. At present, researchers in Japan's national research institutes are not allowed to receive outside remuneration or funds. This has led to the bizarre situation where national laboratory researchers cannot directly receive grants from the Human Frontier Science Program Organization in Strasbourg, France, even although Frontiers is funded largely by MITI and the Science and Technology Agency.
The proposed amendment will also allow Japanese government laboratories to offer larger salaries and longerterm contracts to non-Japanese scientists to try to attract foreign - and in particular Western - scientists to Japan's government institutes. Present laws require that non-Japanese government employees get the same low salaries as their Japanese colleagues but with none of the guarantees of longterm employment.

As another way of opening up MITI laboratories, the ministry has requested $¥ 1,800$ million to provide 'academic discounts' to university researchers wishing to use facilities at MITI laboratories, such as the new microgravity centre in Hokkaido and the ion-engineering research institute in Kansai science city, where brand new high-tech research equipment is available for rent, at a price. 